AperTO - Archivio Istituzionale Open Access dell'Università di Torino

Re-defining the Balance of Power in Lebanon: Sunni and Shiites Communities Transformations, the Regional Context and the Arab Uprisings

This is a pre print version of the following article:

Original Citation:

Availability:

This version is available http://hdl.handle.net/2318/155518

since 2016-07-12T14:13:07Z

Terms of use:

Open Access

Anyone can freely access the full text of works made available as "Open Access". Works made available under a Creative Commons license can be used according to the terms and conditions of said license. Use of all other works requires consent of the right holder (author or publisher) if not exempted from copyright protection by the applicable law. 


\title{
Re-defining the balance of power in Lebanon: Sunni and Shiites communities transformations, the regional context and the Arab uprisings
}

\author{
Rosita Di Peri \\ Università degli Studi di Torino - Torino
}

Dad, are we Sunnis or Shiites? No sweetheart we are Lebanese

Dad, seriously what are we?

My Son.. I am Sunni and your mom is Shiite and you were baptized at a Catholic church

Your sister is Maronite, like her husband and your brother is going to marry a Druze

Dad, did you do that for national unity?

No my son, I did this so that whatever happens

one of us will still be able to go out and buy a loaf of bread

\begin{abstract}
The paper analyzes the transformations occurred in the two most active and relevant communities in Lebanon after the end of the civil war, namely the Sunni and the Shiites, in the light of Arab uprisings and of the changes in the regional balance of power. If the meta-narrative of the 'sectarianization' of the Middle East, especially after 2011, has powered the interpretation of the regional events as marked by the struggle between Sunni and Shiites, the analysis of the transformations of the above mentioned communities in Lebanon and of their impact on the internal and external level, provides one of the best examples against this simplistic representation: the sectarian contraposition is deeply rooted in Lebanon, a pars constituent of its system, but, despite the rhetoric, both communities tend to have more pragmatic and accommodating attitudes instead of exacerbating sectarian confrontation as the afore-mentioned meta-narrative tends to impose. While it is true that each community has witnessed the radicalization of certain positions and that, over the years, major changes are taking place, those have been fuelled by the meta-narrative that is emerging at the regional level and not by a desire to bring the country to the brink of the abyss.
\end{abstract}

Keywords: Lebanon, Balance of Power, Sunni ad Shiites, Arab Uprisings, Confessionalism.

The Arab uprisings have fueled intense debate among scholars of the Middle East and, in general, of political science and international relations. The wave of uprisings that shook the region, which led to the 'death' of some long-time authoritarian leaders, has provided new stimulus to the interpretation of events in this area, until now viewed through the paradigm of the authoritarianism resilience. ${ }^{1}$ Furthermore, the uprisings pave the way to a series of new interpretations of the regional balance of power.

In this regard, before the outbreak of the uprisings, one of the best-known theories was one that emphasizes the existence of an internal split in the Middle East following the division between Sunnis and Shiites with a focus on the identity element (Nasr 2006; Helfont 2009; Cole 2006). Another field of analysis, adopting a constructivist approach, had underlined the reconstitution of renewed pan-Arabism based on new transnational consciousness fuelled by

\footnotetext{
1 On the authoritarianism resilience in the Arab world, the debate is intensive. See, among others, Anderson (2006) and Heydemann (2007). The Arab uprisings propel such debate, also with diverging interpretations. On this last point, see, among others, the Special Issue on Mediterranean Politics $(17,2,2012)$ and, in particular, the Introduction by Cavatorta and Pace (2012) as well as Volpi (2012), Heydemann and Leenders (2011).
} 
new Arab media (El-Nawawy and Iskander 2002; Valeriani 2005; Lynch 2006; Pintak 2009). ${ }^{2}$ Alternatively, on the contrary, other scholars have advanced the hypothesis to be compared with the presence of a 'post Arab' Middle East (Phillips 2014) with most relations among Middle Eastern States, instead of inter-Arab relations, increasingly dependent on those of nonArab States (Iran, Turkey, Israel) (Susser 2007; Noble 2008). Other interpretations, such as those by Valbjørn and Bank, used patterns of analysis borrowed from the past, such as that of the 'Arab Cold War,' amending them to the region's new situation following the 2003 U.S. invasion of Iraq (Valbjørn and Bank 2012). Their argument, using Malcolm Kerr's 1965 book The Arab Cold War, 1958-1964 as a starting point, would seek to employ the prism of the realist interpretation proposed by Kerr, rearranging it to the current situation. Valbjørn and Bank argue that dynamics among the Arab states would be characterized by a new dimension of Arab unity not at the state level but at the society level (Valbjørn and Bank 2007). In other words, they argue that, despite appearances, in today's Middle Eastern policy it would not be sectarian or ethnic divisions that would prevail, such as the supposed growing rivalry between Shiites and Sunni, but dynamics more closely related to the classical raison d'état that would fit into a 'Westphalian type of narrative,' whereby the particular interests of the states would win out. In Valbjørn and Bank's view, an interesting example of such dynamics could be seen in the behavior of certain Arab countries during the war between Hizb Allāh and Israel in 2006. According to the two scholars, the deployment of Saudi Arabia, Jordan and Egypt against the action of Hizb Allāh would not be dictated, as many analysts argue, by a Sunni-Shiite divide, but by the start of what Valbjørn and Bank define as a 'new Arab cold war,' that is, a realignment of Middle Eastern states on the basis of a renewed struggle for leadership in the region.

In this paper, we will move in the direction of the aforementioned 'Westphalian narrative' (Gause 2007). In reconfiguring the regional order in the wake of the Arab revolts, the relations that are being formed among the various Middle Eastern countries appear to be characterized by a form of competition, in which each nation vies for their accreditation or reaccreditation as a hegemonic power at the regional level (Salloukh 2013). ${ }^{3}$ If the identitarian narrative is used heavily to represent the Middle Eastern region as characterized by a redefinition of alliances that would see a Sunni bloc (Saudi Arabia, Egypt, Qațar) lined up against the so-called 'axis of resistance,' in part coinciding with a Shiite bloc (Iran, Syria, Hizb Allāh and Hamās) ${ }^{4}$, then the argument I am putting forward here is that this opposite thesis the so-called sectarianization of the Middle East - should be considered as the new allencompassing meta-narrative that is replacing transnational unifying themes (such as the Palestinian cause and the fight against Israel or, more broadly, pan-Arabism and panIslamism) by proposing a sort of new pan-Islamism based on sectarian basis which I call "sectarian pan-Islamism". Whereas, in the past, transnational unifying themes or ideologies led the Arab states to ongoing clashes between transnational and national aspirations (Barnett 1995: 484-86), today, according to this new dominant meta-narrative, this tension has been transformed in a prevalence of the former over the latter. In this paper, on the contrary, it is argued that national politics play an important role in redefining the geopolitical balance of power in the region. If the Arab uprisings have produced a tangible result, it must be found in the renewed attention that the political strategies of the regional states have acquired in the international arena, which has also been accompanied by the decline of the interests of the Western countries on the Middle East, as the American withdrawal from Iraq (and soon also from Afghanistan) has demonstrated (Malmvig 2013), but also by the

\footnotetext{
2 On the role of Hizb Allāh and its media apparatus, see Lamloum (2009).

3 This thesis was pointed out by several scholars, see, in particular, Salloukh (2013).

4 On the sectarianization of Middle Eastern politics see, among others, Malmvig (2013), Abdo (2013) and Heydemann (2013).
} 
marginalization of those transnational issues (such as the Palestinian cause), which had contributed towards fuelling the transnational pan-Arabist ideology (Norton 2013). This element also appears to have been strengthened, despite appearances, by the insignificant role played by the Arab League. ${ }^{5}$

With this framework in mind, Lebanon and the changes that are taking place there (not only as a direct and indirect consequence of the Arab uprisings and the Syrian crisis) offer interesting insights to understand better the regional politics and alterations in balances and alliances. Internal/external tensions have always characterized the politics of the "country of the Cedars": since before independence, each community had an external "patron" to turn to when applying for funding and/or political support. While in the past it was the European powers and then the Western powers that had this role, in more recent times the various "patrons" are found in individual states of the region. This change in perspective provides an interesting point of view in understanding how Lebanon, historically a kaleidoscope of regional diversity, is one of the pivots upon which regional interests and balance of power are centred and rotate.

Consequently this paper intends to use Lebanon as a mirror of regional changes. The changes in the country's confessional balances have become even more relevant after the Syrian crisis, showing how Lebanon presents, within it, the full spectrum of relationships that can be found at the regional level. Consequently, the modification of the communitarian arrangements may be one way of re-reading the balance of power at the regional level. ${ }^{6}$ The focus of this paper will be on the Lebanese Sunni and the Shi'a communities. For several reasons, but in particular because the split between Sunni and Shiites, as we have seen, this became one of the most robust meta-narratives used to describe the current situation at the regional level. Consequently, the paper will explore how this narrative is fuelled in Lebanon and how fundamental this is in understanding the regional situation.

The Sunni community, represented by the coalition government of $14 \mathrm{March}$, is suffering a process of marginalization that has led, on the one hand, to the marginalization of its leader Sa'd Harīī and, on the other hand, a strengthening of some Salafist movements, which put forward a binary vision interpreting Lebanese politics as a struggle between Sunnis and Shiites. The Shiite community, whose role (with the rise of Hizb Allāh), has become increasingly strategic, is suffering legitimacy turmoil after the escalation of the crisis in Syria and the support provided by the General Secretary of the Party, Hasan Nașrallāh, to Asad. This threatened to negate the claim of trans-confessionalism to which this party has aspired since its creation.

If the polarization of the confessional positions within the Lebanese political spectrum is beyond question, it should be remembered that in the past, however, this "sectarian tension" was partly aimed at keeping alive the consociational system. ${ }^{7}$ The polarization, at least until the explosion of the Syrian crisis, never relied on physical confrontation among the different communities, except in sporadic cases, and the "aggregating factors", although difficult, prevailed over the disruptive ones. However, the Sunni anti-Shiite rhetoric (spread also within the Maronite community) is likely to move the plane of comparison among the

\footnotetext{
5 For an historical view, see Dakhlallah (2012). Some scholars argue, however, that, although weak, institutions such as the Arab League and the GCC are still playing a role in regional politics. See, for example, Phillips (2014).

${ }^{6}$ In this paper we do not analyse in detail the case of the Maronite Christian community, given the low weight that its recent transformations, in terms of considerable marginalization, wield for the regional context. However, where necessary, references to the trajectory of this community will be made, in particular for its position with respect to domestic politics and the other communities.

7 This is the name of the political system of Lebanon whose origins can be found in Lijparth's model, which foresees proportional repartition of the power among the different communities (Lijparth, 1969). In Lebanon in particular, the prime minister has to be a Sunni, the president of the Republic a Maronite and the president of the Parliament a Shiite.
} 
different communities, thereby giving credit to the meta-narrative of sectarianism that has been amplified by the media. ${ }^{8}$ This reading of Lebanese politics seems to create new and less manageable sectarian tensions, and it is clear that these adverse changes are a clear legacy of the "sectarian pan-Islamist" meta-narrative that is emerging at the regional level.

\section{Should Lebanese confessionalism be re-considered in the light of the Arab uprisings?}

Lebanon is one of the most interesting countries to observe as regards the diffusion of the narrative of the fracture between Sunnis and Shiites. The "country of the Cedars" is a kaleidoscope of the confessional diversity that characterizes this region, which can be observed in countries such as Syria and Iraq. In Lebanon, however, the division of political power along sectarian lines has granted certain stability to the system (except during the civil war), due to the power-sharing formula (Fakhoury 2009; Di Peri 2010). In Syria, the power was managed by the Asad family and by the Alawite elites around them (van Dam 1979), according to a neo-patrimonial model that ensured monarchical succession in a republican state to the extent that Syria has been defined a "presidential monarchy". ${ }^{9}$ If Lebanon's economic system espoused a neoliberal vision, also as a result of a laissez-faire policy developed post-independence (Gates 1998) ${ }^{10}$, in Syria as well as in Iraq, economic power has long since been established by a centralized economic policy (Aita 2007; al-Ahsan 1984); only in recent times has centralization been leading the way to the privatization of certain sectors. ${ }^{11}$ Finally, while Lebanon has played a key yet indirect role in Middle Eastern and international relations, at different stages, Syria and Iraq have sought to gain an hegemonic role as regional power, contending with Egypt (or with Saudi Arabia) while also playing the pan-Arabism card (Gause 2007).

The different trajectory that Lebanon has experienced over the years, compared to other countries in the region characterized by multi-confessionalism led to the fact that communities in Lebanon played an important role in the building of the Lebanese state, becoming the mainstay of the country's political and administrative management (Rondot 1989). However, since the end of the civil war, and more distinctly after the war with Israel in 2006, a series of important changes within each community began to emerge showing at least two elements: on the one hand that, now as in the past, the Lebanese communities are not immune to external events and actors, yet they operate in a regional context strongly permeated by instability, and that, in this context, there is a mutual exchange between internal and external in terms of alliances and patronage links; on the other hand that, despite the obvious sectarian splits, however, Lebanese communities demonstrate a certain pragmatism that affects both the alliances within the country and those that each community develops externally. ${ }^{12}$ In the following pages, these two points will be explained through analysis of the trajectories of the Shiites and Sunni communities. These cases will be observed in relation to the national context and their transnational dimension, thus linking the Lebanese case with the re-positioning of various Middle Eastern countries in the wake of the Arab protests.

\footnotetext{
8 See, for example, the titles of some news agencies or commentaries on the Lebanese situation between 2012 and 2013, Foreign Policy Association, in particular http://goo.gl/vchM3z/ Last accessed 8 July 2014; Wilson Center http://goo.gl/SBYd50 Last accessed 8 July 2014; Jerusalem Center for Public Affairs http://goo.gl/FKqxSm Last accessed 8 July 2014; The Middle East Time http://goo.gl/DqNlM3 Last accessed 8 July 2014. See also al-Qaraḍ̄wī and al-Šahal declarations: http://goo.gl/CxzoeR Last accessed 8 July 2014.

9 This term appears in Hinnebusch (2001, p. 67 and following).

10 See also the paper of George Corm in this special issue.

11 On the complex process of economic liberalization, as a result of internal power reorganization but also regional and international factors, see Perthes (1994).

12 On this specific point see also the argumentation of Lorenzo Trombetta in this special issue.
} 


\section{An earthquake in Lebanese politics: the rise of Hizb Allāh and the transformation of the Shiite community}

Since the end of the civil war, the Lebanese Shiite community has undoubtedly received more attention from analysts, scholars and the media. The arrival on the Lebanese political scene of Hizb Allāh and, more generally, the rise and consolidation of the Shiite community have greatly contributed towards changing the sectarian balance, having a major impact both internally and externally. ${ }^{13}$ If the Shiite community in Lebanon was the "great" excluded from the National Pact of 1943- and especially from the new configuration of institutional arrangements provided for by the al-Țầif agreements- the end of the civil war certainly marked an important step forward for the internal accreditation of this community. Whereby, in the course of the Seventies and then the Eighties, the landmark for the Shiite community was the Amal movement, then the official creation of Hizb Allāh (in 1985) contributed greatly to the resizing of Amal, paving the way for its rapid affirmation as one of the most important political actors on the Lebanese political scene (Abukhalil 1990). ${ }^{14}$ More than the other parties in Lebanon, the "Party of God" was more able to adapt to the profound changes that the Lebanese society had to face up to after the civil war (Alagha 2006; Hamzeh 1993). On the one hand, Hizb Allāh provided a voice for the dispossessed, carrying on the legacy of Mūsā alȘadr and building a welfare network for the poor (as well as for martyrs' families) that will endow it with legitimacy nationwide (Flanigan 2009). On the other hand, Hizb Allāh, over the years, and especially in the 2000s, was able to attract, centred around a pan-Arab project, namely the common struggle of the Arabs against the State of Israel, a number of countries and movements in the region, not necessarily Shiites (Hamās, for example, and more generally the Muslim Brotherhood) (Schenker 2013; Campanini 2012). Its ability to play on two different levels, depending on the "systems", showed the extreme adaptability and pragmatism of the party (Di Peri 2014a). This flexibility has been particularly evident since 1992, when, after some hesitation and strong internal discussions, Hizb Allāh finally accepted the al-Tầif Agreement and made the decision to run in the political elections, winning an increasing number of parliamentary seats. ${ }^{15}$ The gradual modification of the strategy of the party at the domestic level and its unerring commitment to building the "society of resistance" did not prevent Hizb Allāh from maintaining a strongly militant external stance, establishing the party's inclusion on terrorist organization lists as well as international stigmatization. ${ }^{16}$ This position, marked by the struggle against the West, the capitalist system and Israel, was clearly apparent from the beginning, as evidenced by the party's programmatic document, the Open Letter. ${ }^{17}$ Equally, it is undeniable that this stance has also been fuelled by the two countries that had contributed the most to the emergence and development of Hizb Allāh, namely Iran and Syria. It should be noted, however, that, in spite of the rhetoric, Syrian support to the Lebanese Shiites groups did not fit within a regional policy characterized by the Shiite-Sunni divide (praised nationally), but rather by a more pragmatic attitude, that is the

\footnotetext{
13 Although there are no data to attest it, in the Seventies the Shiite community became, as far as population is concerned, the most populous Muslim community in Lebanon. Domestically, this clearly contributes to a more demanding role of the Shiite community in the consociational Lebanese system, whereas, externally, it contributes towards redefining strategic alliances.

14 It is obviously wrong to reduce the Shiite community to Amal and Hizb Allāh. Many other relevant Shiites families had and have a relevant role in Lebanese politics. Chorev (2013, 316-319).

15 For example, the expulsion of Șubhī al-Ṭufaylī, Ḥizb Allāh's first Secretary-General. He strongly criticized Ḥizb Allāh's changing attitude towards the Lebanese political system.

${ }^{16}$ Both in the U.S. as, in 2013, in Europe. See Azani (2006) and Birnbaum and Eglash (2013).

17 The text of the Open Letter is reported in Norton $(1987,167-87)$.
} 
identification of the most promising community in Lebanon for its accreditation as hegemonic actor at the regional level (Di Peri 2014).

From the point of view of Hizb Allāh, if, over the years, pragmatism has prevailed at the domestic level, a more militant attitude has emerged at the regional level, which, until the outbreak of the Arab revolts, relied on two important elements: the claim to credit itself as a pan-Arab party open to all communities and representative of the umma and the ability to leverage this militant position to justify the party's domestic policy choices as well as seeking to placate the Shiite hard core (the basis of the party) and the trans-confessional alliances, such as the alliance with Christian Michel 'Awn. This double track and the ability of Hizb Allāh to introduce and establish itself as a new force on the opaque and stale Lebanese political scene (thanks also to the media apparatus ${ }^{18}$ that Hizb Allāh has built over the years as well as due to its efforts at the local level) have in some way contributed towards dampening the critical elements from within, from the Sunni community (in particular by Sa'd Harīin especially after the assassination of his father Rafiq and the creation of the International Commission of Inquiry) ${ }^{19}$ and from the Maronite community (especially beginning with the 33-day war of 2006). ${ }^{20}$

The war against Israel in 2006 proved a watershed for Lebanon but for Hizb Allāh, too. Despite the "divine victory" against the Israel Defense Forces (IDF), Hizb Allāh began to be criticized domestically, for being responsible for the war and the consequent destruction of the country, as well as internationally, for its dependence on Syria and Iran, which would have used Lebanon as a proxy to conduct their struggles against Israel. ${ }^{21}$ The accreditation as a champion of the fight against Zionism, neo-liberalism and capitalist exploitation, also through participation in anti-globalization conferences (Karagiannis 2009), and the good management skills acquired at the administrative level (Harb 2009), enabled the party to accumulate political capital that could be exploited within Lebanon. However, after the war of 2006 and the events of the spring of 2008, a new perception of the "Party of God" was established, which had, as a common matrix, growing hostility towards it by a large part of the population as well as polarization of the sectarian positions. In May 2008, the decision taken by the alSanyūrah government to authorize an investigation into Hizb Allāh's phone network, resulting in the removal of the head of the security at Beirut International Airport (a man close to the "Party of God"), led to a violent reaction by Hizb Allāh. For the first time since the end of the civil war, the country was shaken by two weeks of armed clashes between the "Party of God" and the Lebanese army, which only came to an end through foreign diplomatic efforts (Worth and Bakri 2008).

Neither the long-standing alliance with Christian Michel 'Awn helped Hizb Allāh to regain credibility at a national level. It can therefore be affirmed that Hizb Allāh's adaptability and its ability to use the international and regional context for its domestic accreditation have been questioned to such an extent that, in 2009, Hizb Allāh published its new Manifesto: a document explaining its new stance at the domestic, regional and international levels (Di Peri 2014a). It can be maintained that this new document is also an attempt to show the party's moderate politics worldwide and to regain credibility at the domestic level. In actual fact, in the Manifesto some harsh stances contained in the Open Letter disappear and a more pragmatic attitude prevails (Alagha 2011).

The war in Syria and its consequences for Lebanon are reinforcing Hizb Allāh's inability to continue to juggle the two positions (moderation domestically and militancy externally) for two main reasons: firstly, because the older external supporters of the "Party of God" are

\footnotetext{
18 See Lamloum (2009) and Koch (2008).

19 Khashan (2011).

${ }^{20}$ Interview by the author with a Maronite, Beirut, February 2010.

21 Informal talks by the author in Tyre, January-February 2012; see also Gambill and Abdelnour (2002).
} 
strongly challenged by the international community. Both Asad in Syria and Hāmeneĩ in Iran are showing profound weaknesses in terms of accreditation as regional leaders. Syria does not seem credible given the annihilation policy of a large part of its population. Iran, which had hailed and supported the Arab uprisings as a continuation of the 1979 Iranian Revolution, ${ }^{22}$ to promote itself as a regional champion, has objective difficulties in sustaining its position considering the current situation marked by increasing tension between Sunnis and Shiites. Secondly, because, given Hizb Allāh's unconditional support of Asad, the "Party of God's" strategy of acting as a representative for all Lebanese (and, more broadly, for all Arabs) is gradually crumbling, consequently increasing the anti-Shiite rhetoric in Lebanon within the Sunni (as well as the Christian) community and causing further confessional splits with tangible (and not just political) consequences on the ground (clashes in Tripoli and Sidon disorder). ${ }^{23}$

It should be noted, however, that the official declarations by Hizb Allāh on these issues continue to be highly pragmatic, focusing on the moderation of positions at the domestic level (Lakkis 2013). The point is until when and how the "Party of God" will continue to keep the internal and external stance separate given the developments on the ground in the whole region, the increasingly difficult situation in Syria and its repercussion on Lebanon (Ward 2013).

\section{The difficult management of political heritage: the evolution of the Sunni community in Lebanon}

The Sunni community has played a vital role in the "country of the Cedars". Since the creation of Greater Lebanon in 1920, when Lebanon experienced the inclusion of new territories, mostly inhabited by Shiites and Sunni populations (Di Peri 2009), the political and demographic weight of the Sunni community began to grow along with the leverage of the Christian-Maronites. Each community had its own vision of Lebanon. Whereas, at first, the Maronites would have frowned upon the creation of a Maronite state in Lebanon, in the 1926 Constitution this prerogative was omitted, promoting instead the narrative of a future state for all Lebanese regardless of confessional appurtenance (Zamir 1985). The Sunnis, on the other hand, while initially they would have preferred Lebanon to have been part of a wider pan-Arab project, perhaps assuming its union with Syria, gradually, while defending the "Arabness" of the country, shifted to a more accommodating position. At the forefront of such thinking were the Sunni elite in Beirut, represented by the emblematic figure of Riyād alSulh. ${ }^{24}$ Gradual accommodation and, above all, the prospect of political and economic benefits for both sides led to the creation, in 1943, of the National Pact, an unwritten accord that guaranteed a power-sharing agreement between the two major communities on the basis of their confessional weight. The Sunni community had, from the outset, great significance not only in the institutional arrangements that led to the creation of the Lebanese consociational system, but also in the political life of the country, as evidenced by the considerable power of certain Sunni prime ministers during the period of the First Republic (1943-75).

After the end of the civil war, a new founding pact, the al-Țāif Agreement, further legitimated the importance of the Sunni community through its equivalence to the Maronite community at the expense of the Shiites. The pre-eminence of the Sunni community, even

\footnotetext{
22 "We do not distinguish among Gaza, Palestine, Tunisia, Libya, Egypt, Bahrain and Yemen. We have supported Palestine for thirty-two years, and they are not Šìa. It is not an issue of Šì a or Sunni. It is the protest of a nation against oppression". Hāameneī declaration, Nawrūz Message, Reported in Abdo, 1, 2013.

${ }^{23}$ Informal talk by the author in Sidon and Tyre in 2012. See also the paper of Daniel Meier in this special issue.

${ }^{24}$ Riyāḍ al-Ṣulh was one of the most prominent Lebanese political men, promoter of the Lebanese independence and of the National Pact. See El Khazen (1991).
} 
after political marginalization (in population terms, too), over the Maronite one in the aftermath of the civil war, had as a witness in the re-foundation of its own narrative a controversial and charismatic figure who had played a key role in the reconstruction of the country, namely Rafīq Harīrī. A native of Sidon, a city in southern Lebanon, historically a Sunni stronghold, Harīri was a leading actor in Lebanese politics of the Nineties and helped to strengthen the idea of a "lay" Sunnism with a strong entrepreneurial mindset. Harīin's idea of Sunnism, linked with modernity and progress, used the same buzzwords that Harīin had used to present his pharaonic projects for the reconstruction of the country through his company, SOLIDERE. ${ }^{25}$ The presentation of himself as the new man of Lebanon gave new visibility to the Sunni community who found in Harīrī a powerful, unifying leader. ${ }^{26}$

The Lebanese system, which is based on the consociational model whereby the balance of all the components of society is fundamental, has been shaken, from the Nineties, by two important trends: the increasingly open clash among the three powers of the state, which, post al-Tầif, had been treated de facto as the same (the president of the Republic, the prime minister and the president of the parliament, the so-called troika). This clash led to a paralysis in decision-making. The other aspect was the increasingly evident conflict between Harīin and Hizb Allāh, which had become the country's leading political force. Furthermore, these fractures must be contextualized in the light of the so-called Syrian protectorate (Kassir 2000). From the end of the civil war until the withdrawal of its troops from the Lebanese territory, which occurred in 2005, Syria played a leading role in driving Lebanese politics. The institutional clash between Harīrī and President Lahūd, avowedly pro-Syrian, and between Harīrī and Hizb Allāh, openly supported by Syria, was consumed in the shadow of the Syrian aegis over Lebanon.

While taking into account these dynamics, attention must also be paid to the events following the assassination of Rafíq Harīin in February 2005. A wave of outrage at the murder of the former Prime Minister, for which Syria and its ally Hizb Allāh were accused, led to a polarization of the political positions within the confessional spectrum, which resulted in a radicalization of the conflict between the Sunni political parties aggregates around the March 14 coalition and Hizb Allāh with its March 8 coalition, in particular on two controversial issues: the disarmament of Hizb Allāh (as required by the al-Ṭāiif Agreement and never accomplished) and the initial investigation into the assassination of Rafīq Harīrī ${ }^{27}$ For the first time in its history, the Sunni community felt orphaned, abandoned and marginalized by its politicians who were murdered (not just Harīī, as, in 2005, there were a series of assassinations of anti-Syrian politicians and journalists) and their political weight gradually decreased. This perception is an important factor to be taken into account, considering that, historically, it was the Shiites who were the discriminated and persecuted minority, not only in Lebanon but throughout the Middle East. This is also the reason why the Sunni community has strengthened itself around the Sunni al-Mustaqbal party led, after the dead of Rafīq Harīī, by his son and successor Sacd (Vloeberghs 2012).

\footnotetext{
25 Harīrī was prime minister from 1992 to 1998 and from 2000 to 2004. A highly controversial figure in the Lebanese political sphere, his politics have been defined as authoritarian modernization. Harīrī had strong ties with Saudi Arabia a country where he lived for many years before come back to Lebanon. See Naba (1999).

26 This, of course, not without controversy: Harīrī brought forward an operation of "sunnization", which resulted in the exclusion, cooptation or neutralization of other Sunni politicians in the country.

27 Two political coalitions came to light in the aftermath of Harīrīs assassination: the first, the so-called March 8 (the date of the event convened by Hizb Allāh as a spontaneous reaction to what took place at Harīrī's funeral), which gathered around the "Party of God", Amal and the Christian party of Michel 'Awn; the second, the so-called March 14, from the date of the counter-demonstration organized by the opposing forces, gathered around the alMustaqbal party, which included the Sunni forces but also those of the Christian Lebanese Forces of Samīr Ğa '̌ga and the Druze Progressive Socialist Party of Walīd Ğumblāț, who left the coalition in 2011.
} 
The polarization of the positions of the political forces regarding Harīì's murder investigation saw the option put forward by the 14 March coalition prevail, which called for an international resolution, opposed to Hizb Allāh's alternative, which called for the settlement of the dispute "within" the country. The Security Council Resolution 1595 of 2005 had resulted in the creation of an International Commission of Inquiry (Cataleta 2012), whose work, which led to the arrest of some members of the Syrian intelligence, was interrupted by the Israeli invasion of Lebanon in 2006. It was within this context that, on 30 May 2007, with Resolution 1757 of the Security Council, the Special Tribunal for Lebanon (STL) was set up, becoming operational in 2009. The beginning of the STL's work was preceded by the "2008 events," which were fuelled by several factors: the clash between the two coalitions around the STL as well as their different stances regarding the Israeli invasion, which led, in November 2006, to the resignation of the Shiite ministers from the al-Sanyūra government; the end of the term of President Emile Lahūd, already renewed by special law in 2004, which led to an eighteen-month power vacuum; and the clashes in the refugee camp of Nahr alBārid. ${ }^{28}$

The "2008 events" testify the return to the communitarian option, and the transposition of the political struggle on the grounds of sectarian strife seemed to plunge the country back to the civil war period. After exhausting mediation, promoted from the outside, the parties were able to find a semblance of unity on a new confessional compromise, the Doha Agreement (21 May 2008). The compromise unlocked the impasse that had lasted for months, leading to the election of Michel Suleiman as President of the Republic on 23 May, a revision of the electoral law (passed in September) and the launch of a new political economy. ${ }^{29}$

However, following allegations by the STL levelled at the "Party of God", considered one of the masterminds of the assassination of Harīin, at the beginning of 2011, the political tension that had been kept painstakingly under control in previous years became evident once more and Hizb Allāh withdrew eleven of its ministers from Sa'd Harīrī's government, causing it to fall. The appointment of Nağīb Mīqātī, a Sunni businessman originally from Tripoli, as Prime Minister did not appease the controversy, since his candidacy was put forward by Hizb Allāh and its allies, Michel 'Awn and Walīd Ğumblāt. Protests erupted across the country on the "day of rage" (25 January 2011). ${ }^{30}$ After five months of negotiations, on 13 June 2011, Mīqātī became the Prime Minister of Lebanon. These events reinforced a sense of alienation and powerlessness within the Sunni community, which played an important role in allowing the growth of radical Sunni movements with a strong anti-Hizb Allāh stance and, in general, an anti-Shiite rhetoric. ${ }^{31}$

The political difficulties of the March 14 coalition led by Sa'd Harīīì, in particular due to the lack of a clear political strategy, encouraged the party, albeit in the shadows, to seek the support of Sunni conservative groups, with varying degrees of radicalism, which might prove a useful tool to revive the coalition's basis. ${ }^{32}$ In this context, one of the elements that

\footnotetext{
28 The Fatah al-Islām movement, led by Šayh Šākir al-'Absī, with its basis in the Palestinian refugee camp of Nahr al-Bārid on the outskirts of Tripoli, was severely attacked by the Lebanese army, under the pretext of pursuing an officer responsible for a bank robbery in Tripoli. After months of siege, affiliates to the group were dispersed and al-'Absī disappeared, only to be killed a year later by Syrian security forces. See ICG (2012).

${ }^{29}$ In this context, we should also look at the memorandum of understanding signed the same year between Hizb Allāh and the Lebanese Salafi movement led by Šayh Šahal to promote a renewed agreement between the Lebanese Islamist forces to guarantee national unity. This memorandum, however, was suspended indefinitely from Šahal, the day after his signature. See Salafis freeze memorandum of understanding with Hezbollah, Yalibnan, 19 August 2008 (http://goo.gl/mqAbRH).

30 See Lebanon protests turns violent, al Jazeera, 25 January 2011 (http://goo.gl/60h5Jy).

31 Interview by the author with a Maronite representative in Sidon, February 2012.

32 Sa'd Harīin obviously did not intend to alienate the non-Sunni allies in the coalition and, at the same time, he was afraid to disappoint the expectations and consequent support of Western countries, publicly making an
} 
necessitates emphasis is the high fragmentation that the Sunni community was forced to face in the last decade: while many Sunnis support the 14 March coalition, others have "migrated" to Hizb Allāh (deemed the only political actor capable of fighting the corruption of the Lebanese political system and the last bastion of resistance against Israel), and others have joined radical Islamic groups with a clear anti-system, and often anti-Shiite, attitude.

The problems within the Lebanese Sunni community were amplified at the regional level. Since Rafīq Harīin̄'s commitment to Lebanese politics, ties between the Sunni community and Saudi Arabia have become very close. In general, Lebanese Sunnis have espoused a neoliberal economic policy that has brought them closer to the West. ${ }^{33}$ The political and economic woes of the Harīrì family after Rafīq Harīī assassination irritated Riyadh, however, and the turbulent regional context that emerged from the Arab uprisings of 2011 merely distorted the attention of the Saudi monarchy from the Harīin family.

It should be pointed out, however, that, during his mandate, Sa'd Harīin tried to maintain a pragmatic approach with his regional neighbors; for example, with a visit to Damascus in late December 2009, and through his marriage to a woman from a prestigious Syrian family. ${ }^{34}$ Sa'd Harīrìs visit to Damascus was after the Saudi ambassador's visit, who affirmed that "the steady communication and special relationship between the custodian of the holy shrines and President Assad are exemplary for other Arab leaders to emulate. [...] The fruits of the two countries' distinguished relations ... are reflecting positively, especially in Iraq and Lebanon" (Khashan 2011).

Nonetheless, it seems apparent that the changed domestic circumstances, with the massive influx of Syrian refugees, especially Sunnis, the manifest support of the Sunni community to the forces of opposition to $\mathrm{Asad}^{35}$ (and to some radical Salafi groups in Lebanon), and the lack of political figures gathering the lost legacy of the Harīin clan are exacerbating the problems within the Sunni community, fragmenting them further and fuelling their feelings of dispossession and fragility (Di Peri 2014b).

\section{Conclusion. Internal and regional transformations: bidirectional spillover effect?}

One of the most evident consequences of the Arab uprisings has been the renewed dignity that was given to national policies, for decades crushed under the double-edged sword of authoritarianism and the praise of such transnational ideologies as pan-Arabism. Through this view, we have argued that observing the Lebanese politics and the changes in the balance of power among Muslim communities, which were those most active after the end of the civil war, and between them and the outside world, could provide an original lens through which to interpret the continuous transformations of the regional order, almost exclusively read by the Sunni-Shiite divide.

In Lebanon, it is evident that the Shi'a and Sunni communities are playing a key role in the evolution of national policy. Given the marginalization of the Christian communities and especially of the Maronites in the aftermath of the al-Tāifif Agreement, Muslim communities have acquired a central role in conducting the political game in the "country of the Cedars": the Shiites, through Hizb Allāh, which has been able to gain accreditation at a national and

\footnotetext{
alliance with the radical forces. About connections between al-Mustaqbal and militant Islamist groups in the north of the country, see, among others, Fielder (2007).

${ }^{33}$ Given the economic and political problems of the Harīrī family, Saudi Arabia has become increasingly crucial over the years despite the good relations of Sa'd Harīrī with French and Sarkozy in particular.

${ }^{34}$ See Al Shorfa http://goo.gl/rGSq6f

35 However, as Patrick Seale (2012) pointed out, the forces of March 14, are perceived by the Syrian National Council as the imperialist forces, given the support they receive from Saudi Arabia and the West, and in a regional perspective without Assad, the ties between Lebanese Sunnis and Syrian opposition forces would be, ultimately, very weak.
} 
regional level by skillfully using militancy and pragmatism; the Sunnis, because of their historical role in the construction of Lebanon and, more recently, due to the success of the Harīin family. It is also clear that, at this stage, the two communities are strongly projected outward in defining their own political strategies. On the one hand, by strengthening old alliances, like the involvement of Hizb Allāh in Syria alongside the Asad regime has shown, but also through the strengthening of new bonds with Iran (Devore 2012). On the other hand, through the new connections established with Sunni movements/parties in the Middle East, which called for a revival or re-emergence of the most radical Sunni groups in Lebanon, helping to strengthen a Sunni axis that is spreading increasingly to a regional level (Omayma 2008). The Salafist groups that have strengthened their positions in Tripoli, but also those that have developed around the Šayh al-Asīr in the cities of Sidon, are examples that shift in this direction. ${ }^{36}$

These changes within the communities are nothing new in Lebanon, however. Although the confessional clashes have been represented historically as a fight between Christians and Muslims, and the civil war has helped fuel this narrative, it should not be forgotten that, towards the final stages of the civil war, bloody clashes exploded between Sunnis and Shiites (and between solely Shiites) in the "war of the camps", which led to Iran's intervention with sanctions against their co-religionists. ${ }^{37}$ It should also be pointed out that the presence of Salafist groups in Lebanon cannot be linked solely to the Syrian crisis; it is a phenomenon that dates back to the Fifties (Hamzeh 1997). What is clear, however, is that the intervention of actors on a regional scale with a renewed political weight, such as Qațar, Saudi Arabia, but also the Muslim Brotherhood, have led to the radicalization of certain positions pushing the narrative of sectarianism and its diffusion at a national level (Norton 2012). The contraposition between Saudi Arabia and Iran seems to be framed within the precise dynamics of realpolitik for the control of the region, in which sectarianism is used as the main tool of this realpolitik (Gause 2011, Rivetti 2014).

Can that argument be taken and re-adapted to the national Lebanese context? Has sectarianism been used as a new tool of realpolitik in Lebanon? Have regional developments influenced the national ones? Or are we seeing a sort of a bidirectional spillover effect? Analysis of the main transformations that have occurred within the Shi'a and Sunni communities in Lebanon have demonstrated that the country has been strongly affected by the evolution of regional relations. It cannot be denied that certain polarization of the confessional positions on a sectarian basis is a reflection of the larger polarization of these positions on a regional scale. We have tried to show, nevertheless, how these transformations are deeply rooted in the evolution of relations among the communities, and that such communities have their own historical, political and cultural national roots. Lebanese politics is still alive and, until now, also as part of the Ba'abdā Declaration of 2012 (which stressed the need of the neutralization of Lebanon regarding the Syrian war and the regional events) ${ }^{38}$, the Lebanese political forces have tried to preserve Lebanon from the regional turmoil. The policy of non-confrontation has prevailed to date-not without difficulties-over the narrative of the "sectarian pan- Islamism" that is increasingly looming over the Middle East and over Lebanon.

\footnotetext{
36 On this point see especially Daniel Meier's paper in this special issue.

37 See, in particular The War of the Camps (1986) and Picard (1987).

${ }^{38}$ See the document in General Assembly Security Council, Ba'abdā Declaration, http://goo.gl/v6e07B.
} 


\section{Bibliography}

Abdo, Genevieve (2013). The new sectarianism: the Arab uprisings and the Rebirth of the Shi'a- Sunni divide. Analysis Paper, 29, The Saban Center For Middle East Policy, Brookings Institution.

Abukhalil, Asad (1990). "Syria and the Shiites: Al-Asad's policy in Lebanon". Third World Quarterly, 12, 2, pp. 1-20.

Aita, Samir (2007). "L'Economie de la Syrie peut-elle devenir sociale? Vous avez dit économie sociale de marche?", in Baudoin Dupret, Zouhair Ghazzal, Yussef Courbage and Mohammed al-Dbiyat (eds.), La Syrie au présent: Reflets d'une société, Arles, Actes Sud, p. 541-88.

Al Ahsan, Aziz Syed (1984). "Economic Policy and Class Structure in Syria: 1958-1980". International Journal of Middle East Studies, 16, 3, p. 301-323.

Alagha, Joseph (2011), Hizbullah's documents: From the 1985 Open Letter to the 2009 Manifesto. Amsterdam, Amsterdam University Press.

Alagha, Joseph (2006). The shift in Hizbullah's ideology. Religious ideology, political ideology and political program. Amsterdam, Amsterdam University Press.

Anserson, Lisa (2006). "Searching where the light shines: Studying Democratization in the Middle East". Annual Review of Political Science, 9, p. 189-214.

Azani, Eitan (2006). Hezbollah - a global terrorist organization - situational report as of September 2006, Submission to the US House Committee on International Relations Subcommittee on International Terrorism and Nonproliferation, 28 September.

Barnett, Michael N. (1995). "Sovereignty, nationalism and regional order in the Arab State System". International Organization, 49, 3, p. 479-510.

Birnbaum, Michael and Ruth Eglash (2013). “E.U. declares Hezbollah's military wing a terrorist organization". The Washington Post, July 22.

Campanini, Massimo (2012). L'alternativa islamica. Milano, Mondadori.

Cataleta, Maria Stefania (2012). Le Tribunal spécial pour le Liban et le respect des droits de l'homme. Torino, L'Harmattan.

Cavatorta, Francesco and Michelle Pace (2012). "The Arab uprisings in theoretical perspective - an introduction". Mediterranean Politics, 17, 2, p. 125-138.

Chorev, Harel (2013). "Power, Tradition and Challenge: the Resilience of the Elite Shi'ite Families of Lebanon". British Journal of Middle Eastern Studies, 40, 3, p. 305-323.

Cole, Juan (2006). "A Shiite crescent? The regional impact of the Iraq war". Current History, 105, January, p. 20-26.

Dakhlallah, Farah (2012). "The league of Arab States and Regional Security: towards an Arab Security Community?". British Journal of Middle Eastern Studies, 39, 3, p. 392-411.

Devore, Marc (2012), "Exploring the Iran-Hezbollah relationship: A case study of how state sponsorship affects terrorist group decision making". Perspectives on Terrorism, 6, 4-5.

Di Peri, Rosita (2010). "Il modello consociativo e la sua applicazione al caso libanese", Rivista Italiana di Scienza Politica. 2, p. 1-31.

Di Peri, Rosita (2014). "Les relations syro-libanaises avant et après la crise du système bipolaire”, in D. Bendo Soupou (ed.), Le monde arabe et l'Europe: Entre conflits et paix, Paris, l'Harmattan, p. 159-178.

Di Peri, Rosita (2014b). "Islamist Actors from an Anti-system Perspective: The Case of Hizbullah". Politics, Religion \& Ideology, DOI: 10.1080/21567689.2014.934360

Di Peri, Rosita (2014c), "I movimenti islamisti radicali in Libano: non solo Hizbullah". Rivista di Politica, 2, p. 23-32.

El Khazen, Farid (1991). The communal pact of national identities. The making and politics of 1943 National Pact. Oxford, Center for Lebanese Studies, p. 22-24. 
El-Nawawy, Mohammed and Adel Iskander (2002). Al-Jazeera: how the free Arab news network scooped the world and changed the Middle East. London, Westview Press.

Fakhoury, Tamirace (2009). Democracy and Power-Sharing in Stormy Weather: the Case of Lebanon. Wiesbaden, VS Verlag for Social Sciences.

Fielder, Lucy (2007). "Lebanon's new war". Weekly al Ahram, 24-30 May (http://goo.gl/gjSpQB accessed 22 April 2014).

Flanigan, Shawn. T. (2009). "Hizbullah's Social Jihad: Nonprofits As Resistance Organizations". Middle East Policy, 16, 2, p. 122-137.

Gambill, Gary and Ziad Abdelnour (2002). "Hezbollah: Between Tehran and Damascus". Middle East Intelligence Bulletin, 4, 2.

Gates, Carolyn L. (1998). The Merchant Republic of Lebanon. Rise of an Open Economy. London, The Centre for Lebanese Studies-I. B. Tauris.

Gause, Gregory F. (2007). "Saudi Arabia: Iraq, Iran, the Regional power balance, and the sectarian question". Strategic Insights, 6.

Gause, Gregory F. (2011). Saudi Arabia in the New Middle East. Council on Foreign Relations Special Report, 63, New York, Council on Foreign Relations.

Hamzeh, Nizar (1993). "Lebanon's Hizbullah: from Islamic revolution to parliamentary accommodation". Third World Quarterly, 14, 2, p. 321-337.

Hamzeh, Nizar (1997). "Islamism in Lebanon. A guide to the groups". Middle East Quarterly, 4, 3, p. 47-53.

Harb, Mona (2009). "La gestion du local par les maires du Hizbullah au Liban". Critique Internationale, 1,42 , p. 57-72.

Helfont, Samuel (2009). "The Muslim Brotherhood and the Emerging 'Shia Crescent". Orbis, 53,2 , p. 284-299.

Heydemann, Steven (2013). Syria's uprisings: Sectarianism, regionalization and State Order in the Levant. Working Paper 11, Madrid, FRIDE.

Heydemann, Steven and Reinoud Leenders (2011). "Authoritarian learning and authoritarian resilience: regime responses to the 'Arab awakening". Globalizations, 8, 5, p. 647-653.

Heydemann, Steven (2007). Upgrading Authoritarianism in the Arab World. Analysis Paper, The Saban Center for Middle East Policy, 13.

Hinnebusch, Raymond (2001). Syria: revolution from above, London, Routledge.

Hinnebusch, Raymond (2003). The International politics of the Middle East, Manchester, Manchester University Press.

ICG (2012). Lebanon's Palestinian dilemma: the struggle over Nahr al-Bared, Middle East Report 117 (http://goo.gl/NiO1EO accessed 24 march 2014).

Karagiannis, Emmanuel (2009). "Hizballah as a social movement organization: a framing approach". Mediterranean Politics, 14, 3, p. 365-383.

Kassir, Samir (2000). “Dix ans après, comment ne pas réconcilier une société divisée?". Monde Arabe Maghreb Machrek, 169, p. 6-22.

Kerr, Malcom (1965). The Arab Cold War, 1958-1964. A study of ideology in politics. London, Oxford University Press.

Khashan, Hilal (2011). "Saad Hariri's Moment of Truth". Middle East Quarterly, Winter 2011, p. 65-71 (http://goo.gl/AXPrNE accessed 6 March 2014).

Koch, Olivier (2008). "L'affaire Al Manar en France", in Sabrina MERVIN (ed.) Le Hezbollah, Etat des lieux. Paris, Actes Sud, p. 47-64.

Lakkis, Hassan (2013). "Christian parties, Hezbollah and Amal firm on Orthodox plan". The Daily Star, 25 February (http://goo.gl/uN1u9b accessed 25 May 2014).

Lamloum, Olfa (2009). "Histoire sociale du Hizbullah à travers ses medias". Politix, 3, 87, p. 169-187. 
"Lebanon protests turns violent". al Jazeera, 25 January 2011 (http://goo.gl/60h5Jy accessed 13 April 2014).

Lijphart, Arendt (1969). "Consociational democracy". World Politics, 21(2), pp. 207-225.

Lynch, Marc (2006). Voices of the new Arab public. Iraq, al Jazeera and Middle East politics today. New York, Columbia University Press.

Malmvig, Hellen (2013). Ambiguous endings. Middle East regional security in the wake of the Arab uprisings and the Syrian civil war, DIIS Report, 23.

Muhammad Malik (2009). "Hariri's visit to Damascus receives mixed reactions in Lebanon". Al Shorfa, 21-12 (http://goo.gl/rGSq6f accessed 25 May 2014).

Naba, Rene (1999). Rafiq Hariri. Un homme d'affaires premier ministre. Paris, L'Harmattan.

Nasr, Vali (2006). The Shia revival. How Conflicts within Islam Will Shape the Future. New York, W. W. Norton \& Company.

Noble, Paul C. (2008). "From Arab System to Middle Eastern System. Regional pressures and constraints", in Baghat Korany and A. E. Hillal Dessouki, The foreign policies of Arab States: the challenges of globalization. Cairo, American University of Cairo, p. 67-165.

Norton, Augustus R. (1987). Amal and the Shica. Struggle for the soul of Lebanon. Austin, University of Texas Press.

Norton, Augustus R. (2013). "The Awakened Arab World and its new landscape". International Spectator, 48, 2, p. 63-76.

Omayma, Abdellatif (2008). Lebanon's Sunni Islamists - A Growing Force. Carnegie Paper, Carnegie Middle East Center, 6 (http://goo.gl/3LlZSW accessed 11 January 2014)

Perthes, Volker (1994). "Stages of Economic and Political Liberalization", in E. Kienle (ed.), Contemporary Syria. Liberalization between Cold War and Cold Peace. London, IB Tauris, p. 44-71.

Perthes, Volker (1995). The political economy of Syria under Asad. London, I. B. Tauris.

Phillips, Cristopher (2014). "The Arabism Debate and the Arab Uprising's". Mediterranean Politics, 19,1, p. 141-144.

Picard, Elizabeth (1987). "La politique de la Syrie au Liban. Les développements incontrôlables d'une stratégie ambitieuse". Monde Arabe Maghreb-Machrek, 16, p. 5-34.

Pintak, Lawrence (2009). "Border guards of the "Imagined" Watan, Arab journalists and the new Arab consciousness". Middle East Journal, 63, p. 191-212.

Rivetti, Paola (2014). "La variabile sciita e la politica regionale in Medio Oriente". Rivista di Politica, 2, p. 11-20.

Rondot, Pierre (1989). Les Institutions politiques du Liban. Des communautés traditionnels à l'état moderne. Paris, Publications de l'Institut d'études de l'Orient contemporain.

"Salafis freeze memorandum of understanding with Hezbollah". Yalibnan, 19 August 2008 (http://goo.gl/mqAbRH accessed 10 May 2014).

Salloukh, Bassel F. (2013). "The Arab uprisings and the geopolitics of Middle East". The International Spectator, 48, 2, p. 32-46.

Schenker, David (2013). Sworn Frenemies: Sunni-Shiite Conflict and Cooperation, May 30, 2013, Policy Watch 2081, The Washington Institute (http://goo.gl/tN3hZg accessed 13 April 2014).

Seale, Patrick (2012). “Asad Family values”. Foreign Affairs, 20 March (http://goo.gl/WBdPGB accessed 27 April 2014).

Susser, Asher (2007). Iraq, Lebanon and Gaza: Middle Eastern trends. Tel Aviv Notes, 23 July.

The War of the Camps (1986). Journal of Palestine Studies, 16, 1, p. 191- 194.

Valbjørn, Morten and André Bank (2007), "Signs of a new Arab cold war. The 2006 Lebanon war and the Sunni-Shi'a divide". Middle East Report, 242, p. 6-11.

Valbjørn, Morten and André Bank (2012). "The New Cold War: rediscovering the Arab dimension of Middle East regional politics". Review of International Studies, 38, 1, p. 3-24. 
Valeriani, Augusto (2005). Il giornalismo nel mondo arabo. Roma, Carocci.

Van Dam, Nikolaos (1979). The struggle for power in Syria: politics and society under Asad and the Ba'th Party. London, I.B. Tauris.

Ward, Olivia (2013), "Syria: How Hezbollah became a game-changer", The Star, 23 July, (http://goo.gl/tg4Cqj accessed 13 June 2014).

Vloeberghs, Ward (2012). "The Hariri political dynasty after the Arab Spring". Mediterranean Politics, 17, 2, p. 241-248.

Volpi, Frederic (2012). "Explaining (and re-explaining) political change in the Middle East during the Arab Spring: trajectories of democratization and of authoritarianism in the Maghreb". Democratization, 16, 1, p. 1-22.

Worth, Robert and Nada Bakri (2008). "Hezbollah Ignites a Sectarian Fuse in Lebanon". New York Times, May 18 (http://goo.gl/Lvze02 accessed 12 April 2014).

Zamir, Meir (1985). The Formation of Modern Lebanon. Ithaca, Cornell University Press. 